MEDIKA ALKHAIRAAT : JURNAL PENELITIAN KEDOKTERAN DAN KESEHATAN 1(3): 119-125

e-ISSN: 2656-7822, p-ISSN: 2657-179X

\title{
GAMBARAN FAKTOR RISIKO KEJADIAN GIZI BURUK PADA BALITA DI PUSKESMAS KAMONJI DAN PUSKESMAS TIPO PALU TAHUN 2018
}

\author{
Iras Pratiwi ${ }^{1}$, Darma Ariany ${ }^{1 *}$, Husna Livi ${ }^{1}$ \\ ${ }^{1}$ Program Studi Pendidikan Dokter, Fakultas Kedokteran Universitas Alkhairat, J1. Diponegoro No. 39 \\ Palu 94221, Sulawesi Tengah, Indonesia \\ *Corresponding author: Telp: +6285217533043, email: darma_ariany@yahoo.co.id
}

\begin{abstract}
ABSTRAK
Status gizi merupakan salah satu faktor yang menentukan sumber daya manusia dan kualitas hidup. Masa Balita merupakan proses pertumbuhan yang pesat yang sangat membutuhkan zat gizi yang seimbang agar status gizinya baik, serta proses pertumbuhannya tidak terhambat, karena balita merupakan kelompok umur yang paling sering menderita akibat kekurangan gizi. Untuk tingkat Provinsi berdasarkan data dari Kemenkes gizi buruk balita tahun 2015 di Sulawesi Tengah sebanyak 27,3\% dan turun pada tahun 2016 yaitu 24,2\%. Sehingga perlunya penelitian ini dilakukan agar dapat dijadikan bahan promosi dan pengetahuan sehingga balita bisa tumbuh dengan baik dengan gizi yang normal. Penelitian bertujuan untuk mengatahui gambaran faktor risiko kejadian status gizi buruk pada balita di Puskesmas Kamonji dan Puskesmas Tipo Palu tahun 2018. Metoda yang dilakukan adalah penelitian deskriptif terhadap 7 anak balita yang mengalami gizi buruk di Puskesmas Kamonji dan Puskesmas Tipo Palu tahun 2018. Data diperoleh melalui wawancara terpimpin mengenai status ekonomi, pendidikan ibu, penyakit infeksi, ASI ekslusif dan pola makan pada orang tua anak. Di lakukan analisis distribusi frekuensi menggunakan program SPSS 21. Hasil penelitian menunjukkan bahwa dari 7 anak balita gizi buruk yang ditemukan di wilayah kerja Puskesmas Kamonji dan Puskesmas Tipo Palu tahun 2018; ditemukan faktor risiko sebagai berikut : status ekonomi rendah sebanyak 85,7\%, dengan pendidikan ibu yang rendah sebesar $85,7 \%$, semua berpola makan tidak baik dan disertai dengan penyakit infeksi, dan sebagian besar tidak memperoleh ASI ekslusif (85,7\%). Disimpulkan bahwa karakteristik penderita gizi buruk yang ditemukan di wilayah kerja Puskesmas Kamonji dan Tipo Palu pada tahun 2018 ditemukan faktor risiko Pola makan yang tidak baik, disertai penyakit infeksi, sebagian besar tidak memperoleh ASI Ekslusif, berekonomi dan berpendidikan ibu rendah.
\end{abstract}

Kata Kunci: Gizi buruk, balita, status ekonomi, pendidikan ibu, penyakit infeksi, ASI ekslusif, pola makan

\section{ABSTRACT}

Nutritional status is one of the factors that determine human resources and quality of life. Toddler is a process of rapid growth that really needs balanced nutrition so that the nutritional status is good, and the growth process is not hampered, because toddlers are the age group that most often suffers from malnutrition. For the Provincial level, based on data from the Ministry of Health under-fives in 2015 in Central Sulawesi as much as 27.3\% and down in 2016 which is $24.2 \%$. So the need for this research is carried out in order to be used as promotional material and knowledge so that toddlers can grow well with normal nutrition. The purpose of this research is to know the description of risk factors for the occurrence of malnutrition status in infants in Kamonji and Tipo Palu Health Centers in 2018. The method used is descriptive 
MEDIKA ALKHAIRAAT : JURNAL PENELITIAN KEDOKTERAN DAN KESEHATAN 1(3): 119-125

e-ISSN: 2656-7822, p-ISSN: 2657-179X

research on 7 children under five who suffer from malnutrition in Kamonji and Tipo Palu Health Centers in 2018. Data obtained through guided interviews on economic status, maternal education, infectious diseases, exclusive breastfeeding and eating patterns for parents of children. Frequency analysis was analyzed using the SPSS 21 program. The results showed that of the 7 malnourished children under five who were found in the working area of Puskesmas Kamonji and Puskesmas Tipo Palu in 2018; risk factors were found as follows: low economic status of $85.7 \%$, with low maternal education of $85.7 \%$, all of them had poor diet and were accompanied by infectious diseases, and most did not receive exclusive breastfeeding (85.7\%) . It was concluded that the characteristics of malnutrition sufferers found in the working area of the Kamonji and Tipo Palu health centers in 2018 were found to be risk factors for poor diet, accompanied by infectious diseases, most of which did not receive exclusive breastfeeding, were economical and had low maternal education.

Keywords: Poor nutrition, toddlers, economic status, mother's education, infectious diseases, exclusive breastfeeding, eating patterns

\section{PENDAHULUAN}

Status gizi merupakan salah satu faktor yang menentukan sumber daya manusia dan kualitas hidup. Untuk itu program perbaikan gizi bertujuan untuk meningkatkan mutu gizi konsumsi pangan, agar terjadi perbaikan status gizi masyarakat. Masa Balita merupakan proses pertumbuhan yang pesat yang sangat membutuhkan zat gizi yang seimbang agar status gizinya baik, serta proses pertumbuhannya tidak terhambat, karena balita merupakan kelompok umur yang paling sering menderita akibat kekurangan gizi. ${ }^{1,5}$

Status gizi adalah tingkat keadaan gizi seseorang yang dinyatakan menurut jenis dan beratnya keadaan gizi; misalnya gizi lebih, gizi baik, gizi kurang, dan gizi buruk. Menurut WHO Status Gizi Balita pada Tahun 2016 menunjukkan bahwa Balita yang memiliki Gizi lebih sebanyak 41jt (6\%), Balita Kurus 52jt (8\%) dan Balita Pendek 155jt (23\%) dari jumlah Balita Yang ada. ${ }^{2}$

Status gizi optimal adalah keseimbangan antara asupan dan kebutuhan zat gizi. Dengan demikian, asupan zat gizi memengaruhi status gizi seseorang. Selain asupan zat gizi, infeksi juga ikut memengaruhi status gizi. Pada orang yang status gizinya kurang, masalah kurangnya asupan zat gizi dan adanya infeksi yang biasanya menjadi penyebab. ${ }^{1}$
Gizi Buruk merupakan Penyebab kematian 3,5 juta anak di bawah usia lima tahun (balita) di dunia. WHO memperkirakan bahwa 54\% penyebab kematian balita didasari oleh keadaan gizi buruk. Gizi buruk terjadi bila tubuh tidak mendapatkan zat-zat gizi baik untuk pertumbuhan perkembangan dan juga mengalami kekurangan satu atau lebih zat-zat gizi yang esensial, Gizi buruk adalah kekurangan kalori atau protein (KKP) atau disebut juga protein energi malnutrien (PEM). ${ }^{5,11}$

Prevalensi yang di dapatkan dari balita yang berusia $<5$ tahun dengan melakukan pengukuran parameter antropometri $\mathrm{BB} / \mathrm{U}$ dengan presentasi $<-3$ SD. Hasil data kejadian Gizi buruk di Indonesia menurut Depkes RI tahun 2014 balita yang gizi buruk memiliki prevalensi pada tahun 2007 sebanyak 5,4\% kemudian pada tahun 2010 turun menjadi 4,9\% dan pada tahun 2013 kembali naik menjadi $5,7 \%$.

Gizi Buruk pada Balita, membawa dampak negatif terhadap pertumbuhan fisik maupun mental, yang selanjutanya akan menghambat prestasi belajar. Akibat lainnya adalah penurunan daya tahan tubuh, menyebabkan hilangnya masa hidup sehat balita, serta dampak yang paling serius adalah timbulnya kecacatan, tingginya angka kesakitan dan percepatan kematian (Rahim, 2014). Adapun penyebab dari gizi buruk pada balita karena 
MEDIKA ALKHAIRAAT : JURNAL PENELITIAN KEDOKTERAN DAN KESEHATAN 1(3): 119-125

e-ISSN: 2656-7822, p-ISSN: 2657-179X

kekurangan energi protein, kurangnya zat Besi, adanya gangguan kekurangan Iodium, dan kekurangan Vitamin A. Ini akan menyebabkan Balita yang tidak mendapat cukup makanan bergizi memiliki daya tahan tubuh yang rendah terhadap penyakit sehingga mudah terserang infeksi. ${ }^{11,17}$

Penyebab dari masalah gizi buruk tersebut diakibatkan adanya faktor-faktor yang mempengaruhi status gizi balita. Kemiskinan merupakan salah satu faktor yang memengaruhi terjadinya KEP, namun selain kemiskinan faktor lain yang berpengaruh adalah kurangnya pengetahuan masyarakat tentang makanan pendamping serta tentang pemeliharaan lingkungan yang sehat. ${ }^{11,16}$

\section{METODOLOGI}

Design penelitian yang digunakan adalah Deskriptif dengan pendekatan Cross sectional. Jenis penelitian ini mempelajari dinamika hubungan-hubungan atau korelasi antara faktor-faktor risiko dengan dampak dan efeknya.

Populasi dan Subyek Penelitian

Populasi penelitian : Balita yang ada di Puskesmas Kamonji dan Puskesmas Tipo Palu. Subyek penelitian : Balita yang ada di Puskesmas Kamonji dan Puskesmas Tipo Palu.

\section{Prosedur Penelitian}

1. Penelitian dilakukan pada Balita di Puskesmas Kamonji dan Puskesmas Tipo Palu yang telah terpilih.

2. Setelah balita terpilih yang memenuhi kriteria inklusi di ambil untuk mendapatkan subyek penelitian.

3. Setelah terpilihnya subyek penelitian selanjutnya dilakukan informed consent dengan memberikan informasi dan penjelasan tentang latar belakang, tujuan, cara dan manfaat penelitian kepada orang tua atau wali subyek penelitian.

4. Pengambilan data dilakukan dengan mengajukan pertanyaan dalam bentuk kuisioner kepada orang tua atau wali subyek penelitian.

5. Setelah itu catat semua hasil yang diperoleh pada kertas/buku yang kemudian dipindahkan ke laptop untuk diolah lebih lanjut.

6. Lakukan analisis data yang diperoleh dengan menggunakan program SPSS.

7. Kemudian dilakukan penulisan seluruh data yang telah diperoleh dan dianalisis dalam bentuk yang lengkap.

8. Setelah semuanya selesai dilakukanlah seminar hasil secara lisan maupun tertulis.

\section{Rencana Pengelolaan Data}

Pada penelitian ini analisa data yang digunakan adalah analisa univariat. Analisa ini digunakan untuk mendapatkan gambaran distribusi frekuensi masing-masing variabel penelitian. Pengumpulan data dengan mengambil data primer berupa data kuesioner Kemudian data tersebut diolah secara Deskriptif dan disajikan dalam bentuk grafik dan tabel frekuensi untuk menentukan jumlah dan presentase masing-masing variabel.

\section{HASIL DAN PEMBAHASAN}

\section{HASIL}

Penelitian ini dilakukan di Puskesmas Kamonji dan Puskesmas Tipo Palu pada bulan April sampai bulan Juli tahun 2018 terhadap balita. Pengumpulan data dilakukan dengan cara pengambilan data dengan wawancara langsung untuk diisi pada kuesioner. Data yang diperoleh terdiri dari gambaran faktor risiko kejadian status gizi buruk pada balita. Hasil analisa statistik ditampilkan dengan sistematika sebagai berikut :

\section{Gambaran faktor risiko kejadian status gizi buruk pada balita berdasarkan status ekonomi}

Gambaran faktor risiko kejadian status gizi buruk pada balita berdasarkan status ekonomi dapat dilihat pada tabel 4 berikut ini : 
MEDIKA ALKHAIRAAT : JURNAL PENELITIAN KEDOKTERAN DAN KESEHATAN 1(3): 119-125

e-ISSN: 2656-7822, p-ISSN: 2657-179X

Tabel 1. Faktor risiko status gizi buruk pada balita berdasarkan status ekonomi

\begin{tabular}{lll}
\hline Status Ekonomi & $\mathrm{N}$ & $\%$ \\
\hline Rendah & 6 & $85,7 \%$ \\
Tinggi & 1 & $14,3 \%$ \\
\hline Total & 7 & $100 \%$
\end{tabular}

Dari tabel di atas memperlihatkan interpretasi gambaran faktor risiko kejadian status gizi buruk pada balita berdasarkan status ekonominya didapatkan yang terbanyak itu dengan status ekonomi rendah ada 6 balita $(85,7 \%)$ dari 7 balita. Sedangkan dengan status ekonomi tinggi hanya ada 1 balita $(14,3 \%)$ dari 7 balita yang mengalami gizi buruk.

2. Gambaran faktor risiko kejadian status gizi buruk pada balita berdasarkan Pendidikan Ibu

Gambaran faktor risiko kejadian status gizi buruk pada balita berdasarkan Pendidikan Ibu dapat dilihat pada tabel 2 berikut ini :

Tabel 2. Faktor risiko status gizi buruk pada balita berdasarkan pendidikan ibu

\begin{tabular}{lll}
\hline Pendidikan Ibu & $\mathrm{N}$ & $\%$ \\
\hline Rendah & 6 & $85,7 \%$ \\
Menengah & 1 & $14,3 \%$ \\
Tinggi & 0 & $0 \%$ \\
\hline Total & 7 & $100 \%$
\end{tabular}

Dari tabel di atas memperlihatkan interpretasi gambaran faktor risiko kejadian status gizi buruk pada balita berdasarkan pendidikan ibu didapatkan yang terbanyak itu dengan pendidikan ibu rendah ada 6 balita $(85,7 \%)$ dari 7 balita. Sedangkan dengan pendidikan ibu menengah hanya ada 1 balita $(14,3 \%)$ dari 7 balita. Dan pendidikan ibu tinggi tidak didapatkan pada balita yang mengalami gizi buruk.
3. Gambaran faktor risiko kejadian status gizi buruk pada balita berdasarkan penyakit infeksi

Gambaran faktor risiko kejadian status gizi buruk pada balita berdasarkan penyakit infeksi dapat dilihat pada tabel 3 berikut ini :

Tabel 3. Faktor risiko status gizi buruk pada balita berdasarkan penyakit infeksi

\begin{tabular}{lll}
\hline Penyakit Infeksi & $\mathrm{N}$ & $\%$ \\
\hline Ya & 7 & $100 \%$ \\
Tidak & 0 & $0 \%$ \\
\hline Total & 7 & $100 \%$ \\
\hline
\end{tabular}

Dari tabel di atas memperlihatkan interpretasi gambaran faktor risiko kejadian status gizi buruk pada balita berdasarkan penyakit infeksi terdapat semua balita yang mengalami gizi buruk yaitu sebanyak 7 balita (100\%) itu terkena penyakit infeksi. Sedangkan yang tidak terkena penyakit infeksi tidak di temukan.

4. Gambaran faktor risiko kejadian status gizi buruk pada balita berdasarkan ASI ekslusif

Gambaran faktor risiko kejadian status gizi buruk pada balita berdasarkan ASI ekslusif dapat dilihat pada tabel 4 berikut ini :

Tabel 4. Faktor risiko status gizi buruk pada balita berdasarkan ASI ekslusif

\begin{tabular}{lll}
\hline ASI ekslusif & $\mathrm{N}$ & $\%$ \\
\hline Ya & 1 & $14,3 \%$ \\
Tidak & 6 & $85,7 \%$ \\
\hline Total & 7 & $100 \%$
\end{tabular}

Dari tabel di atas memperlihatkan interpretasi gambaran faktor risiko kejadian status gizi buruk pada balita berdasarkan ASI ekslusif didapatkan yang terbanyak yaitu balita yang 
MEDIKA ALKHAIRAAT : JURNAL PENELITIAN KEDOKTERAN DAN KESEHATAN 1(3): 119-125

e-ISSN: 2656-7822, p-ISSN: 2657-179X

tidak mendapatkan ASI ekslusif sebanyak 6 balita $(85,7 \%)$ dari 7 balita dan hanya ada 1 balita $(14,3 \%)$ yang mendapatkan ASI ekslusif.

5. Gambaran faktor risiko kejadian status gizi buruk pada balita berdasarkan Pola Makan

Gambaran faktor risiko kejadian status gizi buruk pada balita berdasarkan pola makan dapat dilihat pada tabel 5 berikut ini :

Tabel 5. Faktor risiko status gizi buruk pada balita berdasarkan pola makan

\begin{tabular}{lll}
\hline Pola Makan & $\mathrm{N}$ & $\%$ \\
\hline Baik & 0 & $0 \%$ \\
Tidak baik & 7 & $100 \%$ \\
\hline Total & 7 & $100 \%$ \\
\hline
\end{tabular}

Dari tabel di atas memperlihatkan interpretasi gambaran faktor risiko kejadian status gizi buruk pada balita berdasarkan pola makan terdapat semua balita yang mengalami gizi buruk yaitu sebanyak 7 balita (100\%) itu tidak mendapatkan pola makan yang baik. Sedangkan tidak ditemukan balita yang mendapatkan asupan makanan yang baik.

\section{PEMBAHASAN}

1. Gambaran faktor risiko kejadian status gizi buruk pada balita di Puskesmas Kamonji dan Puskesmas Tipo Palu berdasarkan status ekonomi

Berdasarkan penelitian yang telah dilakukan diperoleh hasil bahwa status ekonomi merupakan faktor risiko kejadian gizi buruk. Hal ini sama seperti penelitian yang di lakukan sebelumnya di Semarang pada tahun 2012. Status ekonomi merupakan faktor risiko kejadian gizi buruk dikarenakan rendahnya status ekonomi akan berdampak pada daya beli makanan. Rendahnya kualitas dan kuantitas makanan merupakan penyebab langsung dari gizi buruk pada balita. Status ekonomi yang kurang sebenarnya dapat diatasi jika keluarga tersebut mampu menggunakan sumber daya yang terbatas, seperti kemampuan untuk memilih bahan yang murah tetapi bergizi dan distribusi makanan yang merata dalam keluarga. ${ }^{17,20}$

2. Gambaran faktor risiko kejadian status gizi buruk pada balita di Puskesmas Kamonji dan Puskesmas Tipo Palu berdasarkan pendidikan ibu

Pada penelitian yang di lakukan di Semarang pada tahun 2012 memperoleh hasil bahwa pendidikan ibu merupakan faktor risiko kejadian gizi buruk. Dari hasil sebelumnya sesuai dengan penelitian yang saya lakukan bahwa pendidikan ibu merupakan faktor risiko pada kejadian gizi buruk pada balita.

Hal ini dikarenakan tingkat pendidikan ibu berpengaruh terhadap kualitas pengasuhan balita terutama anak yang masih diasuh oleh ibunya. Kualitas pengasuhan balita yang buruk dan rendahnya pendidikan akan mempengaruhi kualitas dan kuantitas asupan makanan balita yang menyebabkan balita tersebut mengalami gizi buruk. ${ }^{17}$

3. Gambaran faktor risiko penyakit infeksi terhadap gizi buruk pada balita di Puskesmas Kamonji dan Puskesmas Tipo Palu

Pada penelitian ini diperoleh hasil bahwa penyakit infeksi merupakan faktor risiko terjadinya kejadian gizi buruk. Hal ini sesuai dengan penelitian yang di lakukan di RSUD Ulin Banjarmasin bahwa penyakit infeksi merupakan faktor risiko terjadinya gizi buruk pada balita.

Penyakit infeksi dapat menyebabkan gizi buruk karena terdapat hubungan timbal balik antara kejadian penyakit dan gizi buruk. Balita yang menderita gizi buruk 
akan mengalami penurunan daya tahan sehingga rentan terhadap penyakit. Selain itu anak yang menderita penyakit akan memperjelek keadaan gizi melalui gangguan asupan makanan dan meningkatnya kehilangan zat-zat gizi esensial. $^{17}$

Penyakit infeksi disini yang paling banyak diderita oleh balita pada umumnya adalah diare kronik dan ISPA. Hal ini dapat terjadi gizi buruk pada balita yang mengalami diare karena balita akan mengalami asupan makanan dan banyak nutrisi yang terbuang serta kekurangan cairan. Selain itu, balita dengan ISPA yaitu dapat menyebabkan menurunnya nafsu makan sehingga asupan zat gizi ke dalam tubuh anak menjadi berkurang. ${ }^{14}$

4. Gambaran faktor risiko ASI ekslusif terhadap kejadian gizi buruk pada balita di Puskesmas Kamonji dan Puskesmas Tipo Palu.

Pada penelitian yang dilakukan bahwa pemberian ASI ekslusif pada balita merupakan faktor risiko terjadinya gizi buruk. Berdasarkan catatan medik ibu balita yang tidak memberikan ASI ekslusif dikarenakan ASI yang tidak keluar dan anak yang sudah besar.

Pemberian masa ASI ekslusif yang pendek menjadi faktor risiko kejadian gizi buruk karena ASI mengandung zat antibodi sehingga balita yang tidak diberikan ASI ekslusif akan rentan terhadap penyakit dan akan berperan langsung terhadap status gizi balita. ${ }^{1}$

5. Gambaran faktor risiko pola makan terhadap kejadian gizi buruk pada balita di Puskesmas Kamonji dan Puskesmas Tipo Palu.

Pada penelitian ini hasil didapatkan bahwa pola makan merupakan faktor risiko terhadap kejadian gizi buruk pada balita. Sama seperti penelitian sebelumnya yang di lakukan di semarang pada tahun 2012 mendapatkan hasil pola makan merupakan faktor risiko kejadian gizi buruk pada balita.

Pola makan menjadi faktor risiko terhadap kejadian gizi buruk dikarenakan dimana pola makan salah akan mempengaruhi gizi balita, asupan makanan yang kurang disebabkan berbagai faktor antara lain karena persediaan makanan secara adekuat, anak tidak cukup mendapatkan makanan atau salah mendapat makanan seimbang dan pola makan yang salah. Sebagian besar balita dengan gizi buruk memiliki pola makan yang kurang beragam yang artinya kurang mengonsumsi hidangan yang gizi seimbang. Sehingga makanan yang kurang seimbang dan asupan makanan yang kurang akan mempengaruhi status gizi balita. ${ }^{17,22}$

\section{KESIMPULAN}

Berdasarkan hasil penelitian pada 7 anak balita yang mengalami gizi buruk di Puskesmas Kamonji dan Puskesmas Tipo Palu pada awal april-juli tahun 2018 tentang gambaran faktor risiko kejadian status gizi buruk pada balita,

Kesimpulanya sebagai berikut :

1. Distribusi faktor risiko kejadian gizi buruk pada balita berdasarkan status ekonominya banyak terjadi pada status ekonomi rendah yaitu 6 balita $(85,7 \%)$ dari 7 balita.

2. Distribusi faktor risiko kejadian gizi buruk pada balita berdasarkan pendidikan ibu banyak terjadi pada pendidikan ibu rendah yaitu 6 balita $(85,7 \%)$ dari 7 balita.

3. Distribusi faktor risiko kejadian gizi buruk pada balita berdasarkan penyakit infeksi banyak terjadi pada yang beresiko yaitu 7 balita (100\%) .

4. Distribusi faktor risiko kejadian gizi buruk pada balita berdasarkan ASI ekslusif banyak terjadi pada yang tidak ASI ekslusif yaitu 6 balita $(85,7 \%)$ dari 7 balita. 
MEDIKA ALKHAIRAAT : JURNAL PENELITIAN KEDOKTERAN DAN KESEHATAN 1(3): 119-125

e-ISSN: 2656-7822, p-ISSN: 2657-179X

5. Distribusi faktor risiko kejadian gizi buruk pada balita berdasarkan pola makan banyak terjadi pada pola makan yang tidak baik yaitu 7 balita (100\%).

\section{DAFTAR PUSTAKA}

1. Adriani Merryana dan Bambang Wirjatmadi. 2014. Gizi dan Kesehatan Balita. Jakarta: Kencana.

2. Kementerian Kesehatan Republik Indonesia. 2016. Pemantauan Status Gizi di Seluruh Kabupaten/Kota di Indonesia.

3. Kementerian Kesehatan Republik Indonesia. 2013.

4. Hasdianah H.R, Siyoto Sandu, Nurwijayanti. 2014. Pemanfaatan Gizi, Diet, dan Obesitas. Yogyakarta: Nuha Medika.

5. Global Nutrition Report. 2017. Nourishing SDGs.

6. World Health Organization (WHO). 2016. Child Malnutrition.

7. Kementerian Kesehatan Republik Indonesia (Kemenkes). 2016. Hasil Pemantauan Status Gizi Provinsi Sulawesi Tengah Tahun 2016.

8. Puskesmas Kamonji. 2017. Data gizi buruk. Palu.

9. Puskesmas Tipo. 2017. Data gizi buruk. Palu.

10. Dinas Kesehatan Sulawesi Tengah. 2015. Hasil Pemantauan Status Gizi Provinsi Sulawesi Tengah Tahun 2015.

11. Krisnansari Diah. 2013. Nutrisi dan Gizi Buruk. Dahlan Sopiyudin. 2014. Membuat Proposal Penelitian Bidang
Kedokteran dan Kesehatan. Jakarta : Sagung Seto

12. Dahlan Sopiyadin. 2010. Besar Sampel dan Cara Pengambilan Sampel dalam Penelitian Kedokteran Sampel. Jakarta : Salemba Medika

13. Soetjiningsih dan Ranuh Gde. 2012. Tumbuh Kembang Anak Edisi II. Jakarta : Buku Kedokteran EGC

14. Oktavia Silvera, Widajanti Laksmi, dan Aruben Ronny. 2017. Faktor-Faktor Yang Berhubungan Dengan Status Gizi Buruk pada Balita di Kota Semarang Tahun 2017. Jurnal Kesehatan Masyarakat. Di akses 28 Desember 2017.

15. Sholikah Anik, Raffy Eunika, dan Yuniastuti Ari. 2017. Faktor-Faktor yang Berhubungan dengan Status Gizi Balita di Pedesaan dan Perkotaan. Public Health Perspective Journal.

16. Auliya Cholida, Woro Oktia, dan Budiono Irwan. 2015. Profil Status Gizi Balita ditinjau dari Topografi Wilayah tempat Tinggal. Unnes Journal of Public Health.

17. Novitasari dewi. 2012. Faktor-faktor risiko kejadian gizi buruk pada balita.

18. Dahlan s. Besar Sampel dalam penelitian Kedokteran dan Kesehatan. Jakarta: PT Arkans. 2006.

19. Departemen Kesehatan RI. Analisis Situasi dan Kesehatan Masyarakat. Jakarta: Depkes RI. 2004.

20. Supartini Y. Buku Ajar Konsep Dasar Keperawatan Anak. Jakarta:EGC. 2002.

21. Pudjidi s. Ilmu Gizi Klinis Pada Anak. Jakarta:Gaya Baru. 2005.

22. Proverawati, Atikah dkk. 2010. ASI dan Menyusui. Yogyakarta : Nuha Medik. 